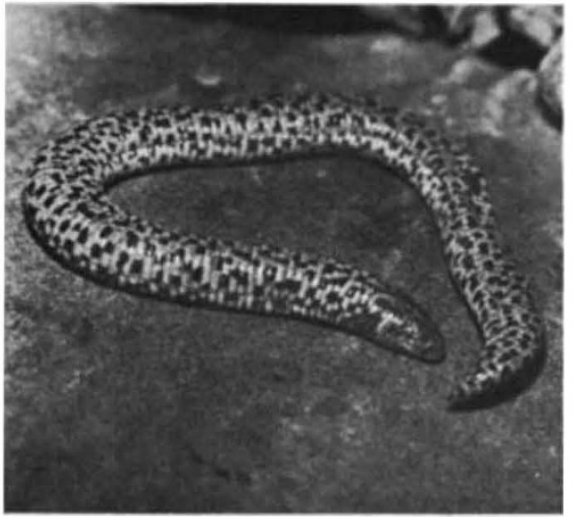

The amphisbaenian Weigmann's Burrowing Lizard (Trogonophis weigmann). The structure of its skull would have rivetted the anatomical and zoological world of the 1920 s. Will it do so today?

membrane bone specializations?

As herpetologists, Bellairs and Gans address the taxonomic problem posed by this unique feature of amphisbaenians. Clearly the group can only with difficulty now be dismissed as aberrant close relatives of lizards (cladists should be particularly engaged by this synapomorphy, not known in other tetrapods). There is some comfort for the classical view: a 'vestige' of cartilage is present and much of the wing in some microteiids may be formed as membrane bone extensions from a more central cartilage anlage. The change may therefore be explicable, but it must have arisen in the fossil record. Where? Has this sort of element been invented by other, now extinct, groups and escaped our notice because of the prophetic powers of morphological canon?

More fundamentally, this bone is not an 'orbitosphenoid' by developmental criteria though it is by anatomy. By not producing cartilage, its cells are not transcribing a normally expressed part of the vertebrate genome. A prop of the homological method has been substantially weakened. Can any experimental embryologists or teratologist now with confidence recognize homologues in treated animals by anatomical or histological criteria? In the 'field-gradient' interpretation of the results of transplantation, are we looking at genome-based homologues or at de novo responses to mechanical and functional stresses independent of any morphotype? The paper of Bellairs and Gans would have rivetted the anatomical and zoological world of the 1920s. It should do so today. $\square$

R. Presley is a senior lecturer in the Department of Anatomy, University College, PO Box 78, Cardiff CFI IXL.

1. Goodrich, E.S. Studies on the Structure and Development of Vertebrates (Macmillan, London, 1930).

2. de Beer, G.R. The Development of the Vertebrate Skull (Clarendon, Oxford, 1937).

3. Jarvik, E. Basic Structure and Evolution of Vertebrates (Academic, London, 1980).

Huxley, T.H. Proc. R. Soc. 9, 381 (1858).

5. May, E. Senckenbergiana biol. 59, 41 (1978).

6. Patterson, C. Linnean Soc. Symp. 4, 77 (1977).

Cytoskeleton components

\title{
A comprehensive catalogue of cytokeratins
}

\section{from Brian Anderton}

CELL biologists with an interest in the cytoskeleton can at last safely feel that the inventory of intermediate filament structural proteins is more or less complete. Largely through the monumental efforts of Werner Franke and his colleagues at the German Cancer Research Centre a catalogue ${ }^{\prime}$ of human cytokeratins has now appeared nineteen different cytokeratin polypeptides in all and each probably a unique gene product.

This is quite remarkable when one considers that the four other members of the intermediate filament class of fibrous organelles have a much more restricted composition: vimentin (one gene expressed in merenchymal cells), desmin (one polypeptide in myogenic cells), glial fibrillary acidic protein (one polypeptide in astrocytes) and neurofilaments (three polypeptides in neurones).

Franke's group has assembled its data by meticulously analysing two-dimensional electrophoretograms of cytoskeletons (enriched in intermediate filaments) from many different epithelioid tissues, cell lines and epithelial tumours (carcinomas). Where necessary, pieces of tissue, including tumours, have been microdissected so as to minimize contamination. The cytokeratin polypeptides range in apparent molecular weights from 40,000 to 68,000 and isoelectric $p \mathrm{H}$ values from 5 to 8 , with a preponderance of the larger proteins being basic and the smaller ones acidic.

Complementary to the chemical analysis, monoclonal antibodies to the cytokeratins have also been used in several laboratories to attack the problem of cytokeratin heterogeneity. As might be expected, some antibodies are more specific than others ${ }^{2-5}$.

The immediate benefits of the catalogue are twofold. First, neoplastic cells seem to express quite faithfully the intermediate filament type of the parent cell; antibodies to the different intermediate filament classes are already being used for tumour diagnosis ${ }^{6,7}$, with commercial exploitation in the pipeline. Monoclonal antibodies to the individual cytokeratins and at least those capable of discriminating between simple and stratified squamous epithelia ${ }^{2.5}$ will further refine diagnosis. Second, intermediate filaments appear at appropriate stages and places during embryogenesis and the complexity of the cytokeratins is likely to make them useful as differentiation markers for embryologists ${ }^{8,9}$.

There remains the question, however, of whether or not cells in culture change their pattern of intermediate filament expression. Many feel that tissue culture of epithelial cells brings about vimentin expression and cytokeratins only would be found in the normal or even neoplastic parent cell.

Franke and his colleagues ${ }^{10}$ have also just reported some interesting findings relevant to this problem. They find that a bovine mammary epithelium cell line cultured in the presence of the hormones hydrocortisone, insulin and prolactin expresses cytokeratins typical of the normal tissue cells and contains no vimentin, but a similar cell line propagated without hormone supplement contains vimentin as well as a cytokeratin pattern reminiscent of that of another bovine epithelial cell line which had been maintained in culture for a long time. This suggests that the pattern of intermediate filament expression may be influenced by the cell's environment. This suggestion is borne out to some extent in vivo by the discovery by Frans Ramaeckers and colleagues that metastasizing carcinoma cells in the pleural fluids express vimentin, whereas the primary and solid secondary tumours contain cytokeratin but no vimentin ${ }^{11}$.

So we are still probably no nearer to knowing what intermediate filaments do in cells and this, after all, is the raison d'etre for studying them. The efforts of cell biologists in this field have, however, provided some very useful knowledge for embryologists and pathologists. Clues to function may perhaps also come from paying more attention to finding conditions which modulate intermediate filament expression rather than rigidly searching for properties of cells dependent on the complement of intermediate filament proteins.

Brian Anderton is in the Department of Immunology, St George's Hospital Medical School, Cranmer Terrace, London SWI7 ORE.

\footnotetext{
1. Moll, R., Franke, W.W., Sthiller, D.L., (ieiger, B. \& Krepler, R. Cell 31, 11 (1982).

2. Lanc, E.B. J. Cell Biol. 92, 665 (1982).

3. Tseng, S.C.G. et al. Cell 30, 361 (1982)

(iigi, O. et al. EMBO J. 1, 1429 (1982).

Debus, E., Weber, K. \& Osborn, M. EMBO J. 1, 1641 (1982).

6. Altmannsberger, M., Weber, k., Holscher, A., Schauer, A. \& Osborn, M. Lab. Invest. 46, 520 (1982).

7. Miettinen, M., Lehto, V-P., Badley, R.A. \& Virtanen, 1. Int. J. Cancer 30, 541 (1982).

8. Jackson, B.W.. Grund, C.. Winter, S., Franke, W.W \& Illmensec, K. Differentiation 20, 203 (1981).

Franke, W.W. Girund, C. Kuhn, C., Jackson, B.W. \& Ilimenswe, K. Differentiation 23, 43 (1982).

10. Schmid, E., Schiller, D.L... Grund, C., Stadler, J. \& Franke, W.W.J. Cell Biol. 96, 37 (1983).

1. Ramackers, F.C.S. et al. Proc. natn. Acad. Sci. U.S.A. (in the press).
} 